J. Perinat. Med.

1 (1973) 252

\title{
Ketamin in obstetrical anesthesia: Clinical and experimental results
}

\author{
W. Dick, R. Borst, L. Fodor, H. Haug, P. Milewski, R. Schumann, \\ E. Traub
}

Dept. of Anesthesiology University of Ulm/Germany

Received March 5, 1973. Accepted April 16, 1973.

In the last several years the Phencyclidin derivative Ketamin has been used more and more clinically in obstetrics as in other fields. Especially in obstetrics some pharmacological qualities of Ketamin led to the assumption that this substance caused fewer anesthesia-induced sideeffects on mother and child.

In the field of obstetrics the range of effects and side-effects of an anesthetic influences the process of birth (specifically active labor, and blood flow to the placenta) as well as the condition of the fetus in the uterus and the condition of the newborn infant immediately after birth and illnesses specific to pregnancy, especially toxemia.

The first extensive clinical experiences with Ketamin in obstetrical anesthesia resulted in widely diversified reports about the effects of Ketamin on active labor $[2,3,15,16]$.

The heart-frequency of the fetus was not affected by these use of Ketamin [15, 16, 21].

The condition of the neonate immediately after birth was judged to be better than after the use of other anesthetic agents $[15,16,21]$.

The positive chronotropic effect of Ketamin and its property of increasing the blood pressure proved useful for inducing anesthesia in hypotonic patients or patients in hemorrhagic shock [18].

However, caution in the use of Ketamin seemed indicated with pre-eclamptic or manifestly eclamptic patients $[1,7,22]$.

The following reports of experiments with Ketamin deal with:

1. Motility of the uterus during birth.

2. The effect of Ketamin on placental bloodflow in animal experiments.

3. The clinical comparison of two series of caesarean sections with different methods of inducing anesthesia, and

\section{Curriculum vitae}

W. Dick, M. D., bas been professor and chief of Section II at the Dept. of Anesthesiology at the University of Ulm/Germany since 1971. After bis internship, be worked for 6 years at the Institute of Anesthesiology at the University of Mainz, during which time be was awarded study-scholarsbips in the US $A$ and England.

In 1970 be became a Uni-

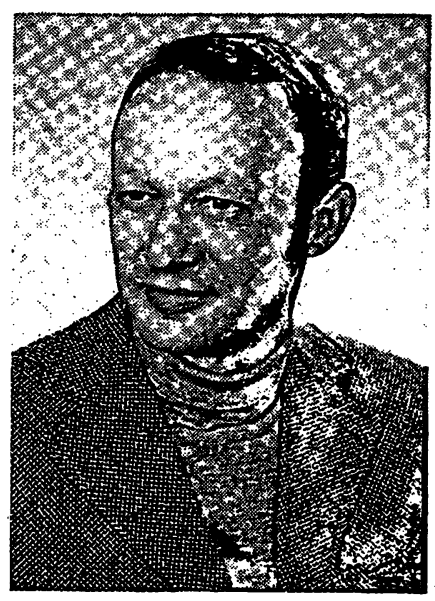
versit)' lecturer (Privat-Dozent) in anestbesiology.

His chief interests are anesthesia and intensive therapy in pediatrics, obstetric anestbesia, resuscitation of the newborn, and prolonged artificial respiration.

4. The determination of the Ketamin-level in the blood of mother and child during the course of anesthesia administered during a caesarean section.

\section{Methods}

\subsection{Ketamin and uterine motility}

Six patients with pronounced cervical dystocia were fitted with an intrauterine pressure-probe. With the use of a Statham element the intraamniotic pressure curves were registered over a ten-minute period while the patient was awake. All 6 patients had received no labor - inducing medication for at least half an hour; dilation of the cervix was approximately 3 to $4 . \mathrm{cm}$.

After the first period of registration, $1 \mathrm{mg} / \mathrm{kg}$ body-weight Ketamin was injected intravenously over a period of thirty seconds. The registration of the intrauterine pressure curve was continued. The registered curves were measured for frequency, basal tension, labor amplitude, and 
duration of contraction. The product, of amplitude and frequency measured in MontevideoUnits, was derived from labor amplitude and labor frequency over a period of ten minutes.

\subsection{Ketamin and placental bloodflow in animal experiments}

At the end of their gestation period (28th to 29th day), 8 albino rabbits were tested for placental bloodflow by using the indircct method of measuring local heat conductivity. Tissue probes of Type $G 1$ and $G 2$ were used as measuring devices, as well as two double-probes inserted as measuring and comparing units; these were constructed especially for checking placental bloodflow [8].

Anesthesia was induced by slow injection of Nembutal@ in a medium dosage of $150 \mathrm{mg}$. A catheter was introduced from the femoral artery into the adbominal aorta; for measuring pressure a Statham element was used. In some individual cases the intrauterine pressure was registered with a pressure probe.

After the heat conductivity probes had been inserted into placenta, they were sutured to the uterus to prevent dislocation.

After completing preparations, we measured the initial bloodflow for about twenty minutes. After that, $2 \mathrm{mg} / \mathrm{kg}$ body-weight Ketamin was injected intravenously over a period of thirty seconds. The mean heat conductivity figure $\lambda$ was derived planimetrically from the curves which were registered over a ten-minute period before and after the injection of Ketamin.

$\left(\lambda-\lambda_{0}\right) \mathrm{xt}$

$\lambda \quad$ represents heat conductivity figure of placenta supplied with blood,

$\lambda_{0} \quad$ represents heat conductivity figure of placenta not supplied with blood,

$t$ represents time.

1.3 Clinical condition of the neonate after Ketamin and Thiopental anesthesia of the mother

One hundred patients on whom a caesarean section was to be perfomed - for either maternalor fetal reasons - received for the induction of anesthesia either 3 or $4 \mathrm{mg} / \mathrm{kg}$ body-weight Thiopental or 1 to $1,5 \mathrm{mg} / \mathrm{kg}$ Ketamin. In the first group after endotracheal intubation anesthesia was continued with $\mathrm{N}_{2} 0 / \mathrm{O}_{2}(4: 2,1 / \mathrm{min}), 0,7$ vol. \% Halothane ${ }^{\circledR}$ and full relaxation; the second group received $\mathrm{N}_{2} \mathrm{O} / \mathrm{O}_{2}$ $1 / \mathrm{min}$ ) and full relaxation.

Each hase of anesthesia induced by Ketamin 1972, was compared with a caesaran section anesthesia from 1971 induced by Thiopentone.

All newborns were evaluated 1 and 5 minutes after birth by the APGAR-score. The statistical comparison of both series was made with the $\mathrm{t}$-Test.

Cases in which caesarean section was indicated for fetal reasons were isolated from both series (28 and 43 cases) and compared separately.

\subsection{Determination of the Ketamin-level in the blood}

In twenty cases of caesarean section the Ketamin-level of venous blood was measured in mother and child (umbilical vein), either at the time of birth (16 cases), or at set intervals after birth, according to the extraction method specified by DrLL and others [6].

None of the patients had received pre-medication before anesthesia was induced, as for example Atropin could interfere with the determining of Ketamin in the blood. In all cases an initial calculation of zero level values was made.

The Ketamin dosage used was $1 \mathrm{mg} / \mathrm{kg}$ body-weight in 18 cases, and $2 \mathrm{mg} / \mathrm{kg}$ body-weight in 2 cases. Anesthesia was continued with $\mathrm{N}_{2} \mathrm{O} / \mathrm{O}_{2}(3: 21 / \mathrm{min})$, after endotracheal intubation and full relaxation until delivery of the child. After delivery 0.5 vol. $\%$ Halothane was added.

\section{Results}

\subsection{Ketamin and uterine motility}

Fig. 1 is an example of an intraamniotic pressure curve, showing labor activity before and after the use of $1 \mathrm{mg} / \mathrm{kg}$ body-weight Ketamin. A decided increase in the frequency of contractions, a slight increase of the pressure amplitude, and a pronounced elevation of the basal tension can be recognized.

Fig. 2 is the evaluation of the uterine contraction frequency of 6 intraamniotic pressure curves. Ten minutes after the administration of Ketamin the contraction frequency is nearly twice as high as before. This difference is significant at the $5 \%$ level.

Fig. 3 shows the basal tension of the uterus before (broken line, lower part) and after (solid

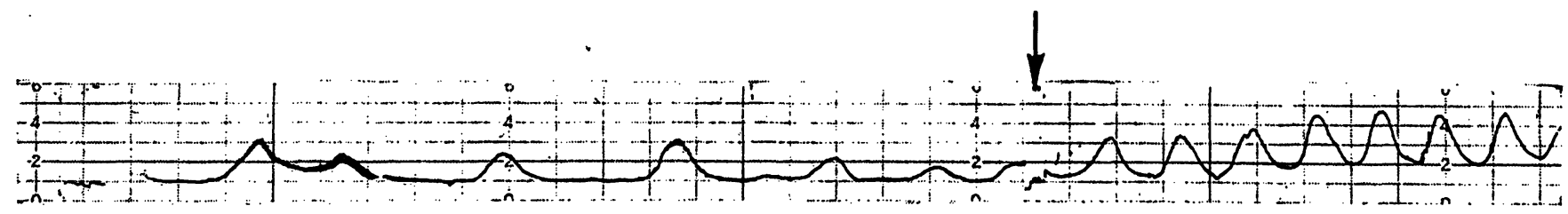

Fig. 1. Intraamniotic pressure curve before and after the injection of $1 \mathrm{mg} / \mathrm{kg} \mathrm{Ketamin} \mathrm{I}$. V. The time of injection is marked by an arrow. 


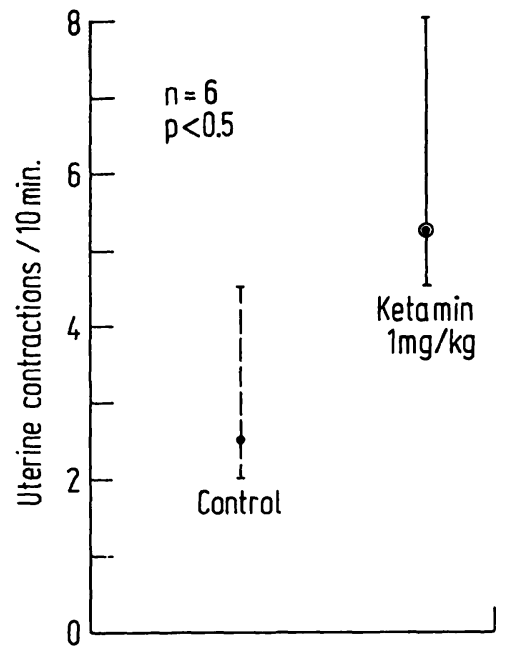

Fig. 2. Laborfrequency of 6 intraamniotic pressure recordings in 6 women before (broken line) and after (solid line) $1 \mathrm{mg} / \mathrm{kg}$ Ketamin I. V. (median and range).

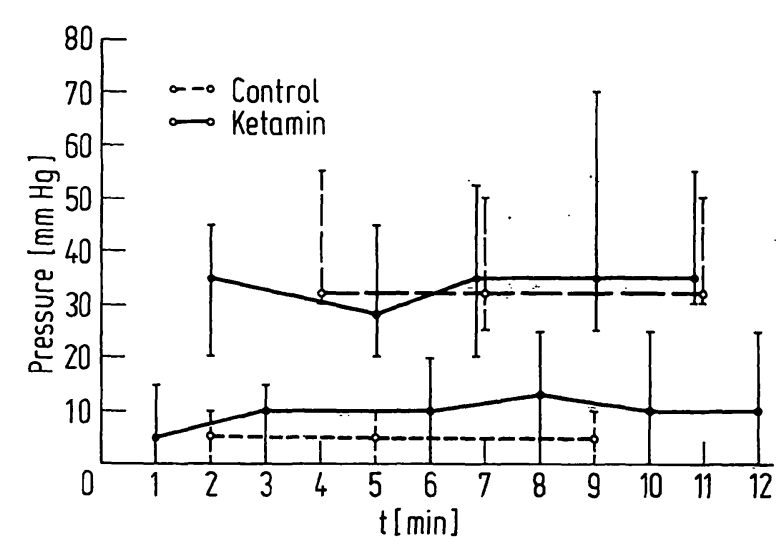

Fig. 3. Basal uterine tension (below) before (broken line) and after (solid line) the administration of $1 \mathrm{mg} / \mathrm{kg} \mathrm{Keta-}$ min. Labor-pressure amplitude (above) before (broken line) and after (solid line) administering $1 \mathrm{mg} / \mathrm{kg}$ Ketamin (median and range).

line, below) administering $1 \mathrm{mg} / \mathrm{kg}$ body-weight Ketamin. The mean basal uterine tension before the injection of Ketamin was $5 \mathrm{mmHg}$; after three minutes it rose $7.5 \mathrm{mmHg}$. It was not possible to prove any significance.

The upper part of Fig. 3 shows the pressure amplitude before (broken line) and after (solid line) administering $1 \mathrm{mg} / \mathrm{kg}$ body-weight Ketamin. No difference in the pressure amplitude after the administration of Ketamin could be demonstrated as compared to the initial values. The product of pressure amplitude and contraction frequency (Fig. 4) - shown in Montevideo-Units - after ten minutes ranges from 95 to $88 \mathrm{M}$. U. Ten minutes after the injection of $1 \mathrm{mg} / \mathrm{kg}$ body-weight Ketamin the mean amplitude-frequency-product is $210 \mathrm{M}$. U. This difference is again significant at the $5 \%$ level.
Summing up, Ketamin influences the uterine motility during birth by increasing significantly the frequency of contractions without influencing labor amplitude. The basal tension is increased slightly, however, without being statistically relevant. There is greater all-over motility of the uterus, mostly caused by the frequency increase.

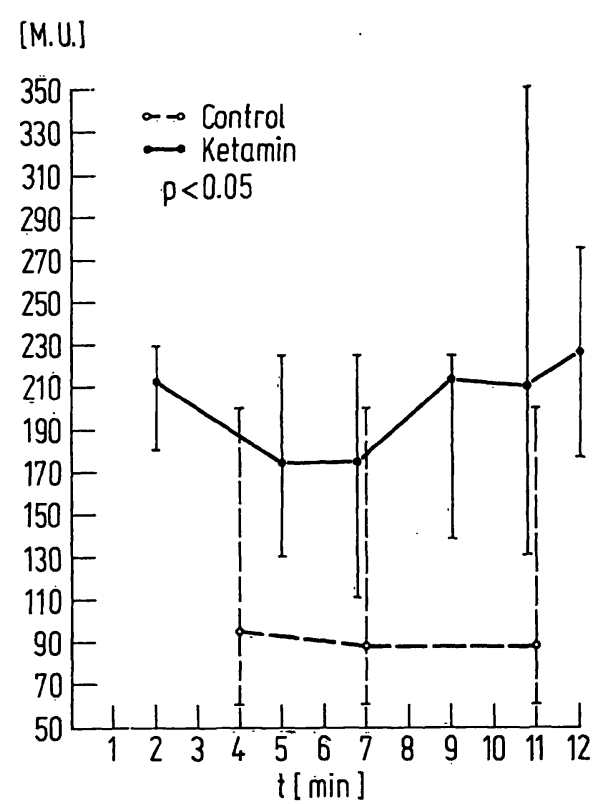

Fig. 4. Uterine motility (labor-pressure $\times$ labor-frequency in Montevideo-Units) before (broken line) and after (solid line) $1 \mathrm{mg} / \mathrm{kg} \mathrm{Ketamin} \mathrm{(median} \mathrm{and} \mathrm{range).}$

\subsection{Ketamin and placental bloodflow in animal experiments}

Fig. 5 shows an original recording with the typical fluctuations of bloodflow. Administering

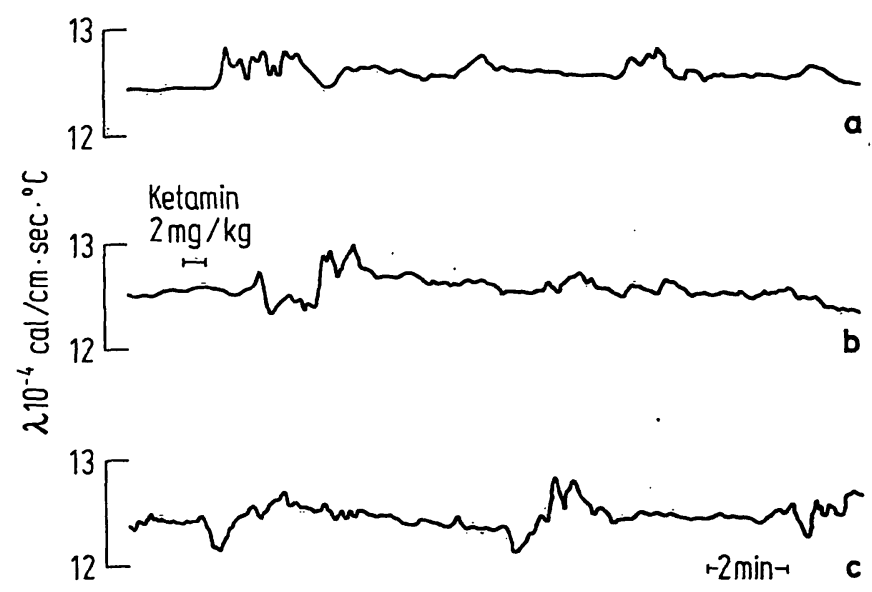

Fig. 5. Original recording of placental bloodflow in rabbits before and after the administration of $2 \mathrm{mg} / \mathrm{kg}$ Ketamin (5b and $5 c$ ). 
$2 \mathrm{mg} / \mathrm{kg}$ body-weight Ketamin caused no recognizable qualitative or quantitative difference (Fig. 5b and 5c).

With an increased dosage of $4 \mathbf{~ m g} / \mathbf{k g}$ there is a marked (Fig. 6), decrease in placental bloodflow as demonstrated by a series of experiments still in progress.

At the same time arterial hypertension and an increase in intrauterine pressure occurred.

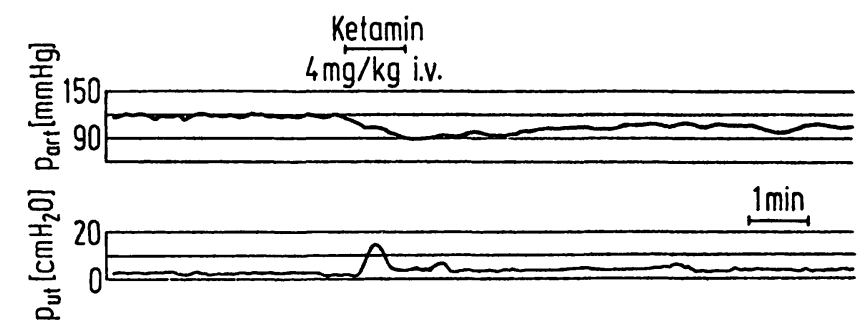

Fig. 6. Original recording of arterial pressure (upper part) and intraamniotic pressure (below) in rabbits before and after the injection of $4 \mathrm{mg} / \mathrm{kg}$ Ketamin.

\subsection{Clinical condition of the newborn after} Ketamin and Thiopental anesthesia of the mother

Fig. 7 shows the mean Apgar-figures of 100 neonates 1 and 5 minutes after delivery by caesarean section. Anesthesia had been induced by either $1 \mathrm{mg} / \mathrm{kg}$ body-weight Ketamin (Group II), or 3 to $4 \mathrm{mg} / \mathrm{kg}$ body-weight Thiopentone (Group I). It is apparent that there is no difference between the two groups.

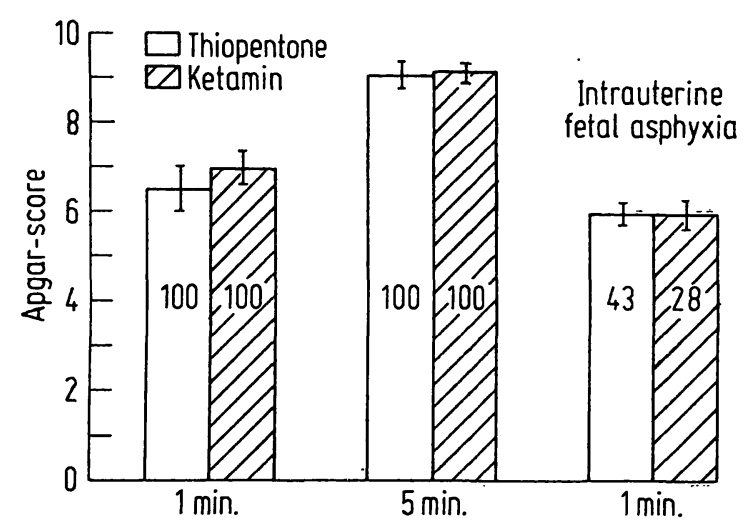

Fig. 7. Mean 1 and $5 \mathrm{~min}$ Apgar-scores of 100 neonates, after the administration of either $1 \mathrm{mg} / \mathrm{kg}$ Ketamin (marked columns) or 3 to $4 \mathrm{mg} / \mathrm{kg}$ Thiopentone (white columns) to the mother for induction of caesarean section anesthesia. The third pair of columns shows the 1 min ApGAR-scores of 28 and 43 neonates, separated from the other 72 and 57 neonates because of threatened intrauterine asphyxia before caesarean section.
The third set of columns shows the 1-minute APGAR-figures of 28 and 43 newborns respectively for whom delivery by caesarean section was necessary. In this group there is also no statistically verifiable difference between the APGARfigures of Ketamin and Thiopental anesthesia.

\subsection{Determination of Ketamin blood-levels}

Fig. 8 shows, in two cases, the development of Ketamin levels in venous blood of mother and child after injection of $1 \mathrm{mg} / \mathrm{kg}$ Ketamin. In Case 1 delivery took place 14 minutes after induction of anesthesia. The level in the maternal venous blood was approximately $0.1 \mu \mathrm{g} / \mathrm{ml}$; decreasing after 16 minutes to $0.06 \mu \mathrm{g} / \mathrm{ml}$.

The venous Ketamin level of the child at delivery was nearly identical to that of the mother. Ten minutes after birth it was approximately $0.05 \mu \mathrm{g} / \mathrm{ml}, 16$ minutes after birth, $0.03 \mu \mathrm{g} /$ $\mathrm{ml}$.

In Case 2 delivery occurred 30 minutes after induction of anesthesia. In this case the venous level of the mother at birth $(0.05 \mu \mathrm{g} / \mathrm{ml})$ was noticeably lower than that of the newborn $(0.11 \mu \mathrm{g} / \mathrm{ml})$. Ten minutes after birth the venous levels of mother and child were approximately identical.

Fig. 9 reflects the reaction of the venous levels of mother and child after administering $2 \mathrm{mg} / \mathrm{kg}$ Ketamin. With this dosage the time between induction of anesthesia and delivery was as before 14 minutes in the first case, and 25 minutes in the second. The patient with the short in-

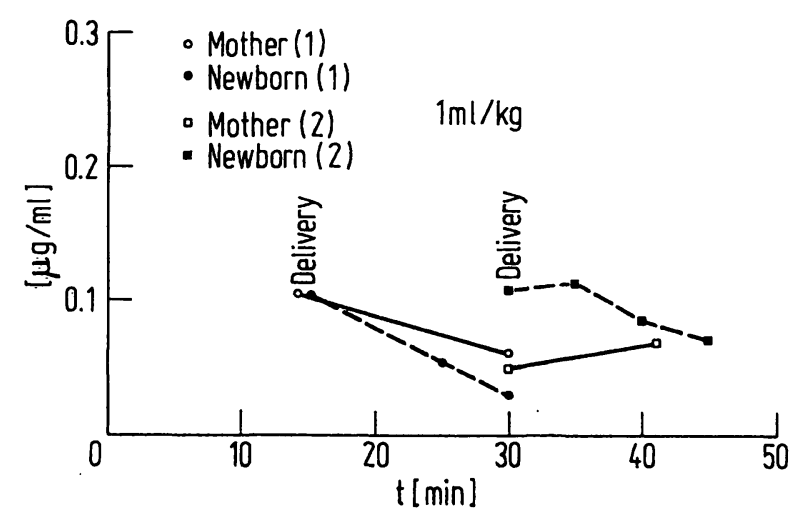

Fig. 8. Maternal and neonatal Ketamin venous blood-levels after injection of $1 \mathrm{mg} / \mathrm{kg}$ (2 cases). Case 1: Inductiondelivery interval $14 \mathrm{~min}$. Case 2 : Induction-delivery interval $30 \mathrm{~min}$. 


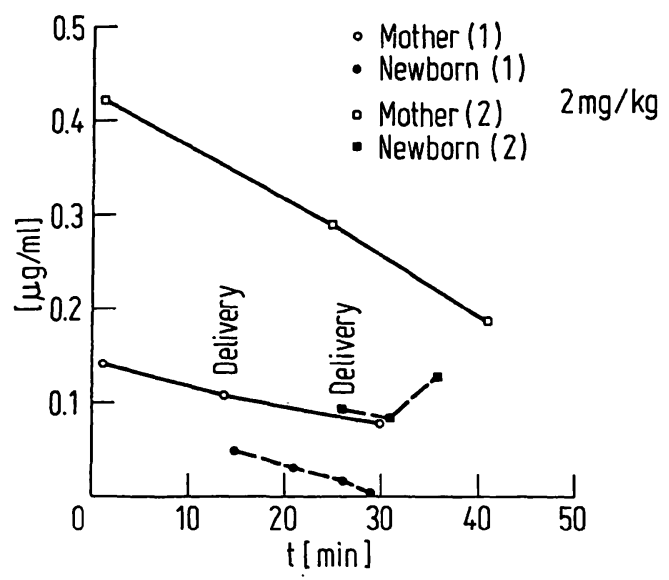

Fig. 9. Maternal and neonatal Ketamin-levels in venous blood after the administration of $2 \mathrm{mg} / \mathrm{kg}$ ( 2 cases). Case 1 : Induction-delivery interval $14 \mathrm{~min}$. Case 2: Inductiondelivery interval $25 \mathrm{~min}$.

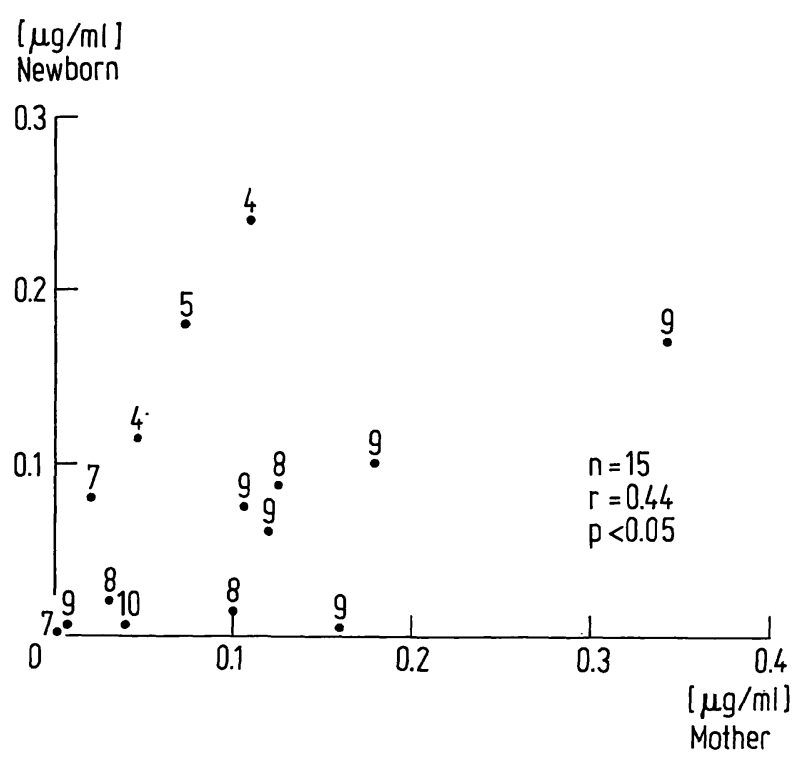

Fig. 10. Correlation of maternal and neonatal Ketamin levels in venous blood at birth. In 15 cases of caesarean section, each point (maternal-neonatal blood-level) is related to the $1 \mathrm{~min}$ APGAR-scores.

duction-delivery time had a venous Ketaminlevel of about $0.11 \mu \mathrm{g} / \mathrm{ml} 14$ minutes after induction; 16 minutes later it had fallen to $0.08 \mu \mathrm{g} /$ $\mathrm{ml}$; the Ketamin-level of the neonate was $0.05 \mu \mathrm{g} /$ $\mathrm{ml} 1$ minute after birth and $0.005 \mu \mathrm{g} / \mathrm{ml} 15$ minutes after birth.

In Case 2 delivery took place 25 minutes after induction of anesthesia. At this time the venous level of the mother was $0.29 \mu \mathrm{g} / \mathrm{ml}$ and dropped to $0.19 \mu \mathrm{g} / \mathrm{ml}$ after 16 minutes. The Ketaminlevel in the umbilical vein of the newborn was $0.095 \mu \mathrm{g} / \mathrm{ml} 1$ minute after birth; 6 minutes after

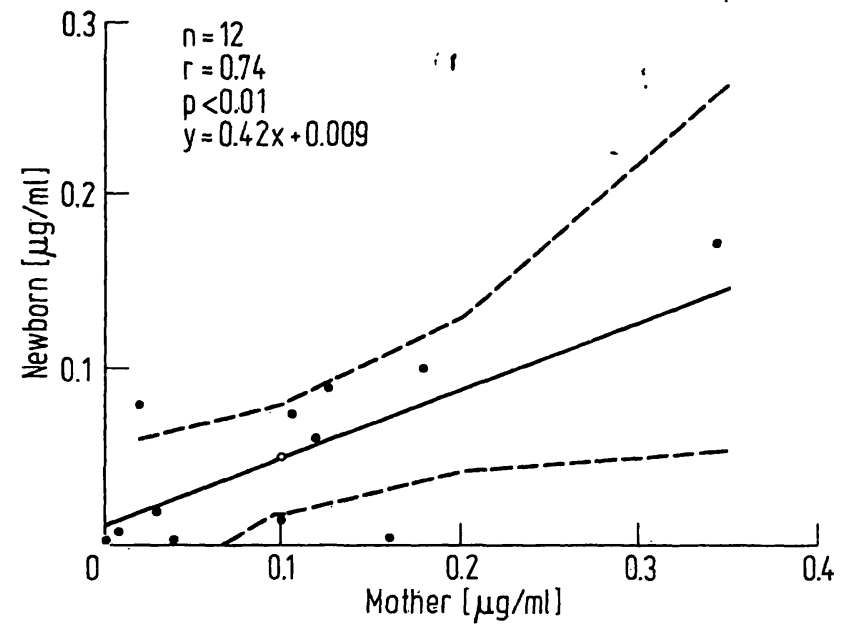

Fig. 11. The same correlation as in Fig. 10 after excluding the 3 cases with low Apgar-scores. Now there is a $1 \%$ significant correlation.

birth it had fallen to $0.085 \mu \mathrm{g} / \mathrm{ml}$, showing a slight increase after 5 minutes.

Fig. 10 shows the maternal blood-levels at birth in 15 caesarean sections, compared to neonatal Ketamin-levels irrespective of the inductiondelivery time.

The individual values are shown with their 1-minute Apgar-score. It is quite obvious that the coordinate points in children with high APGARscores show a more or less similar directional trend, while 3 values (cases of children with low APGAR-scores) are distinctly different. Taking into consideration all fifteen figures; independent of the APGAR=scores, no significant correlation could be established.

If one excludes the three cases of children with the low APGAR-scores from the statistical analyșis (Fig. 11), there is a significant correlation at the $1 \%$ level between the blood-levels of mothers and children at birth, independent of the induction-delivery time.

This illustration (Fig. 12) shows the Ketaminlevels of the newborn at birth in relation to the induction-delivery time. First of all it is evident that at least three figures (pertaining to children with low Apgar-scores), do not follow the trend.

Regardless of whether or not one includes these figures in the evaluation, there is a significant correlation at the $5 \%$ level between the inductiondelivery time and the Ketamin-level of the newborn immediately after birth. 


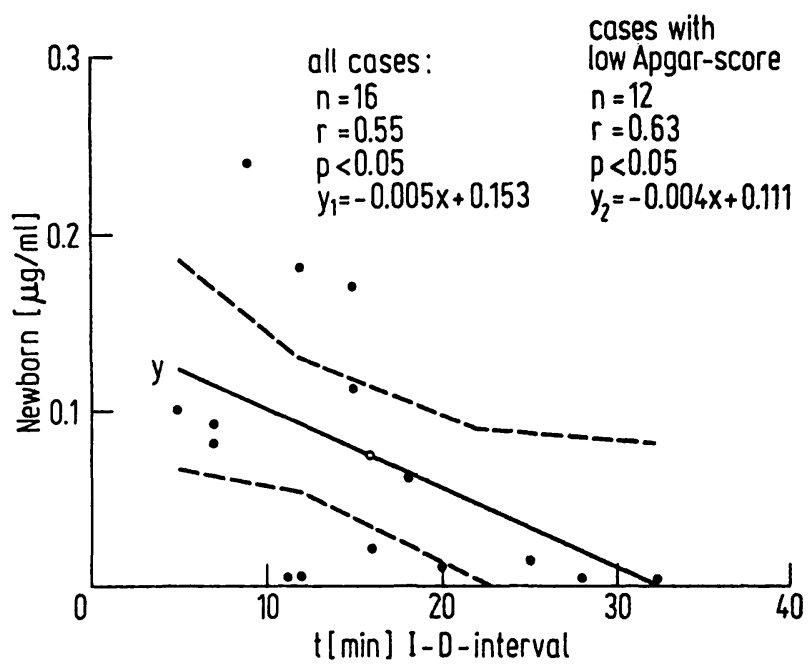

Fig. 12. Neonatal Ketamin-levels in venous blood (umbilical vein) related to induction-delivery intervals. (The total of 16 cases instead of 15, compared to Fig. 10 and 11, is due to an additional case, where neonatal blood-levels, but no maternal blood-levels could be obtained).

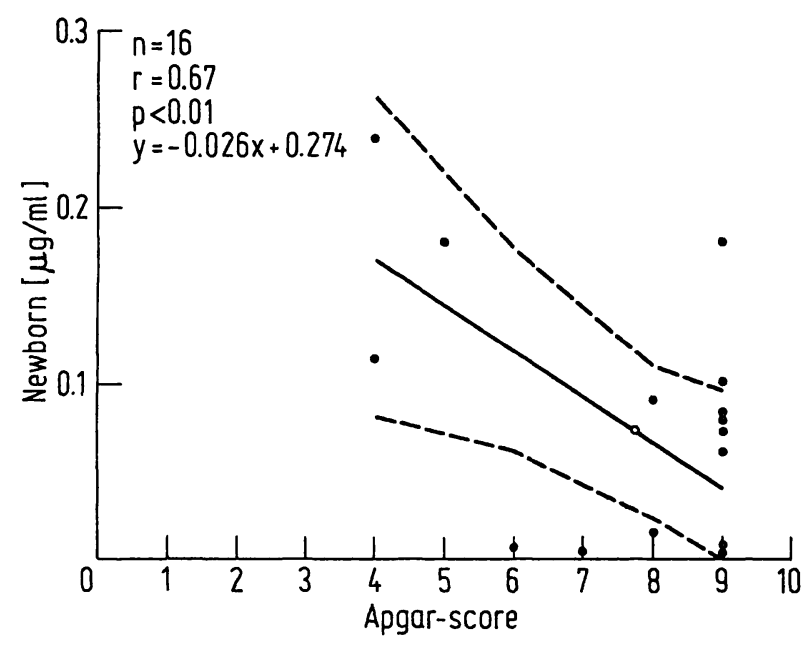

Fig. 13. Neonatal Ketamin.levels in venous blood (umbilical vein) at birth related to the $1 \mathrm{~min}$. Apgar-scores. (The total number of 16 cases instead of 15 cases, compared to Fig. 10 and 11 , is due to an additional case, where neonatal blood-levels, but no maternal blood-levels could be obtained.)

Finally, if one compares the Ketamin-level of the newborn with the 1-minute APGAR-scores (Fig. 13), a significant correlation $(p<0.01)$ is again apparent.

\section{Discussion}

In obstetrics the effects and side-effects of an anesthetic usually extend upon both mother and fetus or newborn (for instance: fall of blood-pressure, decreased placental and fetal blood-flow, hypoxia, acidosis, depressed breathing, etc.). The effects can also apply to a specific condition of the mother, during pregnancy or delivery such as toxemia, protracted delivery, psycho-labile condition, etc.

The same effects and side-effects could also continue to influence the newborn after birth, should the establishment of vital functions be impeded.

The discussion of the above results deals with the general pharmacological qualities of Ketamin only as far as they are of specific interest in obstetrics.

General pharmacological aspects of Ketamin are of importance especially in relation:

a) to the circulatory system of the mother, and

b) to the effects upon her protective reflexes.

Ketamin is generally considered to leave the protective reflexes largely unaffected, when given in therapeutical doses $[2,4,14,15,16]$.

The aspiration of stomach contents during delivery is still one of the main reasons for serious or even fatal comlications in the field of obstetrical anesthesia. This danger exists with all anesthetics. It is our opinion that the use of Ketamin does not reduce the risk of aspiration or regurgitation.

The increase in blood-pressure and the positive chronotropic effect caused by Ketamin can be considered from two contradictory points of view in obstetrics. On the one hand, it is advantageous for inducing anesthesia in cases of hemorrhagic shock or hypotonia; on the other hand, it is disadvanvageous in cases of toxemia with hypertonia. Here, at least, the central Areceptor stimulation has a negative effect. Even though the cerebral blood-flow in healthy patients increases with reduced cerebro-vascular resistance $[11,22,23]$, the increase of systemic blood-pressure as well as the pressure-increase of the cerebro-spinal fluid [7] after the administration of Ketamin must be considered.

In our judgement, the use of Ketamin is therefore inadvisable in all cases ot EPH gestosis.

To date our tests of uterine motility during birth have been made on only six patients. The reason for such a small number of cases is, that only patients with severe cervical dystocia were scheduled for Ketamin anesthesia, or sleepdelivery.

Our results show uniformly a decided increase of contraction frequency after the injection of 
Ketamin. Even though the basal tension, as compared to the initial values, increased, slightly no significance could be verified from this increase any more than from the reaction of labor-pressure amplitude.

The analysis of maximum and minimum values shows clearly a very differentiated pressure reaction in individual patients. The more recent animal experiments by Ksнama [13] can be evaluated in the same way. They showed equally differentiated increases of amplitude without change in the basal tension, increases of amplitude with rising basal tension, and different reactions of laborfrequency.

Horvever, the labor-pressure amplitude/labor-frequency product over ten minutes, expressed in Montevideo-Units, shows a decided increase when compared to the initial values.

The results are important for two reasons: In all cases where increased uterine motility seems contraindicated, or where labor-inhibiting medication is required (for instance, possible rupture of the uterus, or more frequently, possible intrauterine asphyxia of the child), the use of Ketamin anesthesia could possibly have undesirable side-effects on uterine motility. This allows only one conclusion for clinical use: restraint and care in the use of Ketamin in these cases, especially since latest tests show that Succinylcholin also increases uterine motility; a combination of Ketamin and Succinylcholin could possibly result in a very considerable increase of uterine motility.

The extent to which Ketamin alone can actually cause uterine contractions has not yet been determined.

These results also show that in cases of intrauterine asphyxia Ketamin anesthesia should be considered only with reservation; in these cases Ketamin had previously been recommended for caesarean section.

On the other hand, it remains to be seen if the "oxy= tocic" effect of Ketamin, administered in continuous drip infusions, will prove therapeutic during deliveries with weak labor contractions, cervical dystocia etc.

The effect of an anesthetic on uterine motility is of interest in other respects as well. Especially after obstetrical surgery, the ability of the empty uterus to contract is desirable for reducing the loss of blood. A great number of anesthetics in use today, such as Halothane, nitrous oxide, Cyclopropane, Penthrane, etc., lead to considerable relaxation of the uterus and thus possibly to an increased danger of post-surgical bleeding as well as to a still greater blood-loss.

The effects of Ketamin on the uterus are listed above: stimulation of labor frequency, possibly also increase of labor pressure, amplitude and basal tension. These factors, seem to indicate that in certain cases the use of Ketamin could be helpful in decreasing the post-operative blood-loss after obstetrical surgery. However, the clinical significance of this tendency cannot be definitely determined at this time. Our tests have shown that the stimulating effects of Ketamin on the uterus have a maximum duration of only $10-15$ minutes.
This effect of Ketamin could lead to technical difficulties during the 'course of a caesarean section, especially during the actual delivery unless a uterus-relaxing medication, (e. g. Halothane) is given simultaneously

\subsection{Ketamin and Placental bloodflow in animal experiments}

Generally speaking, the aforementioned dosis of $2 \mathrm{mg} / \mathrm{kg}$ Ketamin had no influence upon the placental bloodflow of the rabbits. The changes of the heat conductivity figure lie between +0.2 and $-0.7 \times 10^{-4} \mathrm{cal} / \mathrm{cm} \times \mathrm{sec} \times{ }^{\circ} \mathrm{C}$. Four animals showed an increase of 0.1 to $0.2 \times 10^{-4} \mathrm{cal} / \mathrm{cm} \times \mathrm{sec} \times{ }^{\circ} \mathrm{C}$, three showed no change, and only one showed a decrease in heat conductivity.

The fluctuations in the placental bloodflow-curve are caused by regulative steering processes by changes in the uterine tension, and by fetal influences, since the methods applied also include registration of fetal circulation in the placenta.

To date no tests dealing with the linearity of the relation between the heat conductivity figure and placental bloodflow have been made. However, our experiments show that with slow injections of small doses of Ketamin, a negative effect on placental bloodflow in animal experiments cannot be demonstrated. These findings are no longer valid for increased doses. As far as the clinical use of Ketamin in obstetrics in concerned, there is, above all other reservations, the need for slow injections of smallest possible doses.

\subsection{Clinical condition of neonates after} Ketamin and Thiopental anesthesia of the mother

The statistical comparison of two equally large but not specially-selected groups of caesarean sections (200 cases) shows that the 1 and 5-minute APGAR-scores of the newborns were identical, independent of the use of either Ketamin or Thiopental for anesthesia induction. Even when comparing separately the cases with suspected intrauterine asphyxia, no statistically relevant difference between the two groups could be verified. Our results contradict the findings of authors $[12,14,15,16,21]$. 
At first, there seems to be no explanation. However, the similarly-oriented but much more far-reaching statistical analysis of KRESSIN et al. [12] showed a significant difference, particularly when comparing cases with possible intrauterine asphyxia, having further differentiated among these cases (threatened intrauterine asphyxia). Two aspects remain to be explained when comparing our results with other research work: In the first place, no Halothane was used in the Ketamin series as compared to the Thiopental series. Theoretically, this gave the Thiopental series a less favorable from the start. Furthermore, it must be mentioned that according to concurring reports of obstetricians, delivery under pure Ketamin $\mathrm{N}_{2} \mathrm{O} / \mathrm{O}_{2}$ anesthesia was technically more difficult than with Fluothane added.

Results of our own as well as others have led us to the final conclusion that Ketamin definitely has a place in obstetrical anesthesia. However, this raises the question whether, especially with the indication of possible intrauterine asphyxia, the use of Ketamin for anesthesia induction in a caesarean section can still be recommended. Even with the assumption of slightly more favorable statistical figures, the increased uterine motility under Ketamin, now confirmed by animal experiments and in clinical use, should lead to a certain restraint.

\subsection{Determining Ketamin-levels in the blood}

In conclusion, the experiments for determining Ketamin-levels in the blood during caesarean section anesthesia have led to the following results:

1. At delivery there is a statistically significant correlation between maternal and neonatal blood-levels in neonates with high Apgarscores.

2. This significance is negated if, 1 minute after birth, low Apgar-scores were registered.

3. Independent of the APGAR-scores recorded after birth, there is a linear negative correlation between Ketamin blood-levels in the neonates and the induction-delivery time.

4. There is also a significant correlation between the neonatal Ketamin-levels at birth and the 1minute Apgar-scores, i. e., higher Apgarscores correspond to the lower neonatal Ketamin-levels.

5. No correlation between the 1-minute Apgarscores of the neonates and the induction-delivery time could be shown.
These results demonstrate that, first of all, the condition of newborns after delivery by caesarean section correlates to the residual concentration of Ketamin in the blood of the umbilical vein. These residual concentrations are in turn dependent upon two factors:

a) The time-lapse, between induction of anesthesia in the mother and actual delivery.

b) The blood-levels of the mother at birth.

With a single induction doses of $1 \mathrm{mg} / \mathrm{kg}$ Ketamin it can be assumed that the Ketamin-level in the fetus, depending upon the induction-delivery time, will fall by 0.006 to $0.008 \mu \mathrm{g} / \mathrm{ml}$ every two minutes.

Disturbances in this decreasing ratio are obviously explainable first by disturbances of the maternal - fetal or fetal - maternal metabolism and gas exchange through the placenta. This assumption is supported by the fact that in 3 neonates with low 1-minute Apgar-scores (4 to 6) after delivery the Ketamin blood-level was too high in relation to the induction - delivery time.

The same newborns also showed Ketamin-levels too high when compared to the maternal blood-levels.

One can assume a linear correlation between maternal and fetal blood-levels only when there is no disturbance of the placental metabolism and gas exchange; the correlation between neonatal Ketamin blood-levels and the inductiondelivery time seems to be less affected by these disturbances. On the other hand, there is a marked absence of correlation between the 1-minute Apgar-scores and the inductiondelivery time. Theoretically, this correlation should have been present because of the relation between neonatal Ketamin blood-levels, Apgar-scores, and the inductiondelivery time.

Obviously, there are other influences involved here, for instance, the simultaneous continuous administration of nitrous oxide, which, has a negative influence upon the APGAR-scores after the ten-minute level has been reached.

The determination of the course of the concentration in the newborns at different times after birth $(1 \mathrm{mg} / \mathrm{kg}$ in two cases) confirms the correlation between concentration and time even after delivery.

However, in one case, after application of $2 \mathrm{mg} / \mathrm{kg}$ Keta$\mathrm{min}$ to the mother, the blood of the newborn showed a renewed rise of the Ketamin concentration. The cause could be a short-term-deposit of Ketamin in the infant, with ensuing redistribution. But no definite conclusions can be drawn until more figures are available.

Independent of the induction-delivery time, the Ketamin blood-level of the newborn will correlate with the maternal blood-level 
when there are no particular materno-fetal or feto-maternal exchange disturbances. In addition, the condition of the neonate is definitely dependent upon the residual concentrations which in turn are dependent upon the inductiondelivery time.

\section{Summary}

We have attempted to clarify in clinical and animal experiments some qualities of Ketamin which are relevant to obstetrical anesthesia:

1. Ketamin and uterine motility.

2. Ketamin and placental bloodflow (animal experiments).

3. Effects of Ketamin on the newborn in caesarean section as compared to the effects of Thiopental anesthesia.

4. Ketamin blood-level in newborns in correlation to several other factors.

According to the results of the experiments, Ketamin definitely increases uterine motility during birth, usually producing a rise of labor-frequency. The results of the animal experiments when using the normal clinical dosage $2 \mathrm{mg} / \mathrm{kg}$, show no influence on placental bloodflow. With increased dosages, however, $(4 \mathrm{mg} / \mathrm{kg}$ ), there is, according to preliminaty observations, a definite decrease in placental blood-flow.

In 100 cases of caesarean section selected at random, there was no difference in the condition of newborns whose mothers had received either Thiopental or Ketamin anesthesia. These results are, however, contradictory: further differentiation between the cases of threatened intrauterine asphyxia is called for.

At least in cases noenates delivered in good condition, there is a statistically significant correlation between Ketamin blood-levels of mothers and neonates. Beyond this, there is a linear negative correlation between the Ketamin blood-levels of the newborn at birth and the induction-delivery time. The newborns' Ketamin levels also correlate significantly with the 1-minute ApGARscores.

These findings lead to the following conclusions:

1. Ketamin should be used with caution when there is suspicion of threatened intrauterine asphyxia, all the more so as the combination of Ketamin with Succinylcholin has an additive effect. Furthermore, Ketamin should be injected slowly in the smallest dose possible for induction of obstetrical anesthesia, in order to avoid decrease of the placental bloodflow.

2. Ketamin definitely has a place among other obstetrical anesthetics, especially in caesarean section. However, we could not determine qualities superior to other anesthetics (e. g. Thiopentone).

3. The neonatal blood-levels at birth are definitely dependent upon the maternal blood-levels. This also leads to the recommendation that the doses of Ketamin should be as small as possible.

Inasmuch as neonatal blood-levels at birth correlate with the induction-delivery time and with the 1-minute APGARscores, Ketamin by itself calls for no minimum limitation of the induction-delivery time in caesarean section. However, one must consider that with falling blood-levels the maternal analgesia and anesthesia becomes insufficient; this simultaneously requires more $\mathrm{N}_{2} \mathrm{O}$ where by a limitation of the induction-deliverytime (under 10 minutes) is necessary.

Keywords: Anesthesia, animal experiments, APGAR-scöre, caesarean section, Ketamine, newborn, uterus (contractions, motility).

\section{Zusammenfassung}

Ketamin in der geburtshilflichen Anästhesie - Klinische und experimentelle Untersuchungen

In klinischen und tierexperimentellen Untersuchungen wurde versucht, einige für den geburtshilflich-anästhesiologischen Bereich relevante Eigenschaften von Ketamin abzuklären.

1. Ketamin und Uterusmotilität.

2. Ketamin und Placentadurchblutung (Tierexperiment). 3. Die Auswirkungen von Ketamin auf das Neugeborene im Rahmen der Sectio caesarea im Vergleich zur Thiopentalanästhesie.

4. Kindliche Ketaminblutspiegel in Relation zu verschiedenen Faktoren.

Nach den vorliegenden Untersuchungen erhöht Ketamin die Uterusmotilität unter der Geburt, vorwiegend auf Kosten einer Wehenfrequenzerhöhung.

Die tierexperimentellen Befunde lassen bei klinisch üblicher Dosierung von Ketamin keinen Einfluß auf die Placentadurchblutung erkẹnnen. Bei höherer Dosierung tritt nach vorläufigen Beobachtungen eine deutliche Verminderung der Placentadurchblutung auf.

Wurde Ketamin zur Einleitung der Sectio-Narkose verwendet, so unterschied sich der Zustand der Neugeborenen nicht von dem anderer Neugeborener, deren Mütter zur Anästhesieeinleitung Thiopental erhalten hatten.

Wenn Neugeborene nach sectio caesarea in gutem Allgemeinzustand geboren wurden, bestand eine statistisch signifikante Korrelation zwischen mütterlichen und kindlichen Ketaminblutspiegeln. Darüber hinaus ergibt sich eine lineare negative Korrelation zwischen kindlichen Ketaminblutspiegeln zum Zeitpunkt der Geburt und der Einleitungs-Entwicklungszeit. Die kindlichen 
Ketaminblutspiegel korrelieren ebenso signifikant mit den 1-Minuten-APGAR-Werten.

Diese Befunde lassen folgende Schlußfolgerungen zu:

1. Ketamin sollte gerade dann mit Vorbehalt verwendet werden, wenn der Verdacht auf eine drohende intrauterine Asphyxie besteht.

2. Ketamin sollte langsam in möglichst niederer Dosierung zur Einleitung der geburtshilflichen Narkose injiziert werden.

3. Ketamin hat durchaus einen anderen Anästhetika ebenbürtigen Platz in der geburtshilflichen Anästhesie, speziell bei der Sectio caesarea. Eigenschaften, die anderen Anästhetika überlegen wären, konnten wir nicht feststellen.

4. Die kindlichen Blutspiegel zum Zeitpunkt der Geburt hängen entscheidend von der Höhe der mütter-

Schlüsselworte: Anästhesie, ApgaR-score, Ketamin, Neugeborenes, Plazenta (-Durchblutung), Sectio caesarea, Tierexperiment, Uterus(-Motilität), Wehen. lichen Blutspiegel ab. Auch hieraus läßt sich die Empfehlung ableiten, Ketamin so niedrig wie nur möglich zu dosieren. $\mathrm{Da}$ die kindlichen Blutspiegel zum Zeitpunkt der Geburt sowohl mit der Einleitungs-Entwicklungszeit, als auch mit den 1-Minuten-APGAR-Werten des Neugeborenen korrelieren, wird die Einleitungs-Entwicklungszeit bei der sectio caesarea durch Ketamin selbst nicht nach unten limitiert.

$\mathrm{Zu}$ bedenken bleibt jedoch, daß mit abfallenden Blutspiegeln die mütterliche Analgesie und Anästhesie unzureichend wird, andererseits für die gleichzeitige erforderliche Verwendung von $\mathrm{N}_{2} \mathrm{O}$ eine deutliche Limitierung der E-E-Zeit nach unten (unter 10 Minuten) erforderlich ist.

\section{Résumé}

La Kétamine en anesthésie obstetricale, résultats cliniques et expérimentaux

Les auteurs ont tenté par l'expérimentation clinique et animale de mettre en évidence dans le domaine obstétrique-anesthésique quelques propriétés essentielles de la Kétamine.

$1^{\circ}$ Ils ont étudié l'actirité de la kétamine sur la motilité utérine.

$2^{\circ}$ Sur le débit placentaire (expérimentation animale). $3^{\circ}$ Sur l'état des enfants nés par césarienne en comparaison avec l'anesthésie au Thiopental.

$4^{\circ}$ Le taux sanguin néo-natal de Kétamine en correlation avec plusieurs autres facteurs.

En accord avec les résultats expérimentaux, ils ont observé que la Kétamine augments la motilité utérine pendant l'accouchment, ce qui se traduit par une augmentation de la fréquence des contractions. Aux doses usuelles de $2 \mathrm{mg}$ par kilo, les résultats obtenus lors d'expérimentations animales ne montrent pas de modifications du débit placentaire. Cependant, en utilisant des doses plus élevées (4 mg par kilo) on observe en accord avec les observations antérieures, une chute du débit placentaire. On n'observa aucune différence entre l'état néonatal d'enfants nés par césarienne sous anesthéșie à la Kétamine, et celui d'enfants nés après anesthésie au Thiopental sur une série de 100 enfants. Ces résultats montrent cependant certaines contradictions dont l'explication pourrait être necessaire à la distinction entre divers cas de menace d'asphyxie intra-utérine.

Dans les cas où les nouveau-nés étaient en parfait état à la naissance, on nota une corrélation statistiquement sig- nificative entre les taux de Kétamine dans le sang maternal et dans celui de l'enfant. Il existe notamment une corrélation linéaire négative entre le taux de Kétamine dans le sang de l'enfant, et la durée de l'extraction. Les taux sanguins de kétamine présentent egalement une bonne corrélation avec la score d'APGAR à 1 minute.

De ces faits, on peut tirer les conclusions suivantes:

$1^{\circ}$ La Kétamine devra être utilisée avec très grande prudence lorsqqe on sousconnera un danger d'asphysie intra utérine, d'autant plus que la Kétamine présente un effect cumulatif avec la succinylcholine. D'autre part, le produit sera injecté lentement aux doses les plus faibles possibles afin d'évicer une chute du débit placentaire.

$2^{\circ}$ La kétamine possède une place importante parmi les autres anesthésiques obstétricaux utilisables en cas de césarienne, cependant, on n'a pas encore pu déterminer sa supériorité vis à vis d'autres produits (par exemple le Thiopentone).

$3^{\circ}$ Le taux de Kétamine dans le sang de l'enfant dépend exclusivement du taux dans le sang maternel. Il faut donc utiliser des doses de produit aussi faibles que possible. D'autant plus que la concentration du produit dans le sang de l'enfant présente une bonne corrélation tant avec la durée de l'extraction qu'avec le score d'Apgar. Toutefois, on doit considérer qu'en diminuant le taux du produit dans la circulation maternelle, on risque d'aboutir à une analgésie et une anesthésie insufisante, ce qui nécessitera l'utilisation simultanée de $\mathrm{N}_{2} \mathrm{O}$. Dès lors, il est indispensable de fixer une durée entre l'induction de l'anesthésie et l'extraction de l'enfant, cette durée devra être inférieure à 10 minutes.

Mots-clés: Anésthésie, Afgar-score, césarienne, contractions utérines, débit placentaire, expérimentation animale, Kétamine, motilité utérine, nouveau-né. 


\section{Bibliography}

[1] Bosomworth, P. P.: Ketamine in obstetrical anesthesia. Anesth. Vigile Subvigile 1 (1970) 153

[2] Bovill, J. G., D. L. Coppel, J. W. Dunder, J. MOORE: Current status of ketamine anaesthesia. Lancet, 1 (1971) 1285

[3] Chodoff, P., J. G. Stella: Use of CI-581, a phencyclidine derivative for obstetric anesthesia. Anesth. Analg. 45 (1966) 527

[4] Corssen, G., J. R. Hayward, J. W. Gunter, E. H. Groves: A new parenteral anesthesia for oral surgery. J. Oral. Surg. 27 (1969) 627

[5] Dick, W., W. D. Jonatha, P. Milewski, E. Traub: Untersuchungen zum Verhalten des Uterustonus unter der Geburt während der Ketamine-Anaesthesie. II. Mainzer Ketamin-Symposion, 7./8. 4. 1972

[6] Dill, W. A., L. Chucot, Tsun Chang, A. J. Glazko: Determination of ketamine in blood plasma. Anesthesiology 34 (1971) 73

[7] Gardner, A. E., B. E. Olson, M. Lichtiger: Cerebrospinal-fluid pressure during dissociative anesthesia with ketamine. Anesthesiology 35 (1971) 226

[8] Golenhofen, K., H. Hensel, G. Hildebrandt: Durchblutungsmessung mit Wärmeleitelementen in Forschung und Klinik. Thieme, Stuttgart 1963

[9] Hodshon, B. J., A. 'T. Ferrer, V. L. Brechner, A. K. CHO: A gas chromatographic assay procedure for ketamine in plasma. Anesthesiology 36 (1972) 506

[10] Knox, J. W. D., J. G. Bovill, R. S. J. Clarke, J. W. Dundee: Clinical studies of induction agents. XXXVI. Ketamine Brit. J. Anaesth. 42 (1970) 875

[11] Kreuscher, H., J. Grote: Die Wirkung des Phencyclidinderivates Ketamine (CI 581) auf die Durchblutung und Sauerstoffaufnahme des Gehirns beim Hund. Anaesthesist 16 (1967) 304

[12] Kressin, G., E. Saling, D. Reichwein: Zustand der Kinder nach Sectionarkose mit Ketamine und Thiobarbital. In: Saling, E., J. W. Dudenhausen, Perinatale Medizin Band IV 5. Deutscher Kongreß für Perinatale Medizín (Berlin, 1.-5. November 1972) Thieme, Stuttgart 1973

[13] Kshama, Jawalekar, S., S. R. Jawalekar, V. P. MATHur: Effect of ketamine on isolated murine myometrial activity. Anesth. Analg. 51 (1972) 685

[14] Langrehr, D., P. Alar, J. Andjelković, I. Kluge: Zur Narkose mit Ketamine (CI 581): Bericht über erste Erfahrungen in 500 Fällen. Anaesthesist 16 (1967) 308

[15] Langrehr, D., W. Stolp, J. Kluge, A. HaAs: Ketamine-Anaesthesie für geburtshilflich-gynäkologische Eingriffe. Z. prakt. Anästh. 3 (1970) 145

[16] LANGREHR, D.: Ketamine in obstetrical anesthesia. Anesth. Vigile Subvigile 1 (1970) 153

[17] Oyama, T., F. Matsumotio, T. Kudo: Effects of ketamine on adrenocortical function in man. Anesth. Analg. 49 (1970) 697

[18] Peter, K., R. KLose, H. Lutz: Ketanest zur Narkoseeinleitung beim Schock. Z. prakt. Anästh. 5 (1970) 396

[19] Pflüger, H.: Hämodynamische Veränderungen bei intravenös applizierbaren Narkosemitteln. Fortschr. Med. 88 (1970) 1249

[20] Rodrigues Lima, J., H. E. BarReto: Influence of ketamine on uterine constractions during labor. 'J. Bras. Gineco. 71 (1971) 223

[21] Stolp, W., D. Langrehr, K. Sokol: Zur Anwendung von Ketamine in der geburtshilflichen Anaesthesie. Z. Geburtsh. und Gỹäk. 169 (1968) 148

[22] Takeshita, H., Y. Okuda, A. Sari: The effects of ketamine on cerebral circulation and metabolism in man. Anesthesiology 36 (1972) 69

[23] Traber, D. L., R. D. Wilson; L. L. Priano: The effect of alpha-adrenergic blockade on the cardiopulmonary response to ketamine. Anesth. Analg. 50 (1971) 737

[24] Tsun Chang, A. J. Glazko: A gas chromatographic assay for ketamine in human plasma. Anesthesiology 36 (1972) 401

Prof. Dr. W. Dick

Dept. of Anesthesiology Univiersity of Ulm Prittwitzstr. 43

D-7900 Ulm/Germany 